\title{
关于土木工程结构设计与地基加固技术认识
}

\author{
袁志强 \\ 中海宏洋地产(银川)有限公司 \\ DOI:10.32629/btr.v1i6.1673
}

[摘要] 土木工程, 英文名为 “Civil Engineering”, 主要是指建造各类土地工程设施的科学技术的统称, 涵盖众多子工程, 如, 房 屋建筑工程、道路工程、铁路工程、隧道桥梁工程、堤坝工程等等, 对人们日常生活起到一定影响。基于此, 本文就对土木工 程结构设计与地基加固技术展开探究, 以期为土木工程结构设计与地基加固工作提供参考依据。

[关键词] 土木工程；结构设计；地基加固技术；注意事项

在我国社会经济迅速发展的今天, 土木工程行业发展速 度迅猛, 为城市增添力诸多风采。但是随着土木工程数量增 多、规模增大, 使得其在施工阶段需要注意的细节多样化, 稍微不注意, 就会出现结构稳定性下降, 不利于土木工程行 业的发展。因此, 建筑施工单位展开土木工程结构设计与地 基加固工作非常有必要, 本文就对两项工作展开探究, 以期 推动土木工程行业的发展。

\section{1 土木工程结构设计的要点阐述}

众所周知, 土木工程结构设计的优劣, 直接会影响到土 木工程的整体质量, 以期后期投入使用的安全性、稳定性和 耐久性, 如果土木工程结构设计不合理, 那么后期投入使用 时就会频繁出现问题, 缩短使用寿命 ${ }^{[1]}$; 如果土木工程结构 设计合理, 那么其使用寿命就会增加, 并满足人们多样化的 生活需求。针对此种情况, 建筑施工单位就需要做好土木工 程结构设计工作, 详细掌握土木工程结构设计要点, 具体做 到以下几点:

一是, 钢筋混凝土结构设计要点阐述。土木工程在建设 期间, 最常使用到的施工材料就是钢筋混凝土, 可以说, 钢筋 混凝土质量直接决定了土木建筑工程的整体稳定性, 意义非

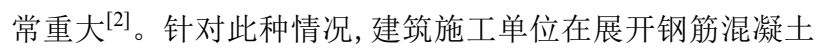
结构设计工作时, 就需要关注多方面内容: 第一, 建筑施工单 位严格检查钢筋混凝土施工材料质量, 确保所使用的施工材 料质量好、性能高, 能够满足施工需求, 在施工阶段不会出现 工程变更、施工进度延长等问题。第二, 建筑施工单位在展 开钢筋混凝土结构设计时, 需要详细核查钢筋混凝土的配置 条件, 确保钢筋混凝土的所有配置条件都符合要求, 在施工 中能够发挥出作用, 有效提高钢筋混凝土的整体质量。第三, 建筑施工单位需要详细检查混凝土原材料, 确保混凝土原材 料中含有的水泥、骨料、砾石等配比合理, 提高混凝土性能, 从而有效降低施工成本, 帮助建筑施工单位获取到最大化经 济效益。

二是, 土木工程的承重结构设计要点阐述 ${ }^{[3]}$ 。现阶段, 我 国城市内部所开展的土木工程多数都是房屋建筑工程, 这类 工程对承重结构有着较高的要求, 如果承重结构不合格, 极 易增加房屋倒塌问题, 影响房屋建筑工程的抗震性能。针对
此种情况, 建筑施工单位要想有效提高土木建筑工程施工质 量, 确保工程项目稳定性, 就需要注重承重结构的设计工作, 且在承重结构设计过程中努力提高建筑材料的强度等级, 使 得横墙能够发挥承重功能, 降低工程出现坉塌的几率。

三是, 土木工程的剪力墙结构设计要点阐述 ${ }^{[4]}$ 。剪力墙 结构在使用过程中具有承载建筑物负荷力的作用, 是建筑工 程的核心骨架, 保证建筑物的墙体和楼板之间质量, 进而可 以在地震发生过程中减少建筑物发生损坏的程度, 意义重 大。针对此种情况, 建筑施工单位就需要在土木工程中积极 展开剪力墙结构设计, 并在设计中严格注意以下几点: 第一, 剪力墙设计严格遵循对称性原则, 有效保证墙面结构的刚度 和质量平衡, 起到抗震作用。第二, 剪力墙设计过程中, 建筑 施工单位需要注重边缘构件的约束性管理, 根据土木建筑工 程具体情况, 合理设置剪力墙尺寸比例, 然后针对性选择边 缘构件, 确保所选择的边缘构件质量符合要求, 能够发挥出 作用。第三, 剪力墙设计过程中, 建筑施工单位需要对剪力墙 所使用的钢筋展开细致分析, 合理设计, 从根本上提高剪力 墙设计质量, 让土木工程的抗震性能得到提升。

\section{2 土木工程的地基加固方法介绍}

土木工程在展开地基加固工作时, 所能使用的方法多种 多样, 如, 加筋法、胶结法、挤压法、排水加固法、换填法、 化学加固法等等等 ${ }^{[5]}$, 无论建筑施工单位选择哪种施工方法, 其在施工阶段都需要注意众多事项, 力求能够有效保证土木 工程地基的稳定性, 延长土木工程的使用年限。以下就对土 木工程的地基加固方法进行细致分析, 力求能够为施工技术 人员提供有效参考。

一是, 土木工程地基加固中使用排水加固法 ${ }^{[6]}$ 。排水加 固法, 英文名为 “drainage consolidation method”, 主要 是指在地基中设置砂井 (袋装砂井或塑料排水带) 等坚向排 水体, 然后根据建筑物本身重量进行加载, 使土体中的孔隙 水排出, 逐渐固结, 地基发生沉降, 强度逐步提高的方法。将 此种方法应用到土木工程地基加固施工中, 可以有效施工现 场地基质量, 但是此种方法使用过程中还需要严格注意以下 两个方面内容: 一方面, 排水加固法使用时, 需要合理选择地 基添加物质, 确保所选择的地基添加物质合理, 能够有效起 
到施工排水作用。另一方面, 排水加固法使用完毕后, 施工人 员还需要做好后续维护工作, 确保不会受到外界因素影响而 无法发挥出作用, 有效提高地基加固效果。

二是, 土木工程地基加固中使用换填法 ${ }^{[7]}$ 。换填法, 英文 名为 “Replacement Method”, 主要是指将基础地面以下一 定范围内的软弱土挖去, 然后回填强度高, 压缩性较低, 且没 有侵蚀性的材料的方法。在土木工程地基加固工作中使用换 填法, 既可以减少沉降量; 还可以提高地基承载力, 意义重 大。与此同时, 建筑施工单位在使用换填法时, 需要注重施工 条件、施工环境的优化与改善工作, 从而让换填法可以顺利 应用, 有效提高土木工程施工现场地基的稳定性。

三是, 土木工程地基加固中使用化学加固法。化学加固 法, 英文名为 “chemical grouting”, 主要是指将化学溶液 或股结剂灌入土中, 让土粒胶结起来, 进而提高土体的力学 强度, 起到加固作用。建筑施工单位要想在土木工程地基加 固中顺利使用此种方法, 就需要严格注意以下两点: 一方面, 施工前期, 建筑施工单位需要对施工现场进行打扫, 清洁, 确 保施工现场没有障碍物, 清洁平整。另一方面, 建筑施工单位 还需要提前勘查施工现场, 确保施工现场周边环境的湿度、水 文条件都符合要求, 不会让化学溶液发生反应, 顺利起到加 固作用。

四是, 土木工程地基加固中使用加筋法。加筋法, 英文名 为 “reinforcement method”, 主要是指在土中加入条带等 抗拉材料, 改善土的力学性能, 提高土的强度和稳定性的方 法, 由于此种方法的抗震性能好、造价低, 因此, 目前在土木 工程中被广泛使用。

\section{3 土木工程地基加固工作中需要注意的事项分析}

由于土木工程地基加固工作繁琐, 任务量大, 且方法众 多, 如果方法选择不准确, 就会降低地基加固效果, 难以发挥 出实质性作用。因此, 建筑施工单位在展开地基加固工作时, 需要严格注意以下两点:

一是, 土木工程地基加固工作中合理选择加固方法。不
同的地基加固方法使用环境不同, 所起到的作用也不同, 因 此, 建筑施工单位在选择地基加固方法时, 需要充分结合建 筑工程施工现场环境、施工技术等内容, 确保所选择的地基 加固方法合理, 能够有效发挥出作用, 提高地基加固效果。

二是, 土木工程地基加固工作中合理设置抗震等级。土 木工程抗震等级会受到诸多因素影响, 因此, 建筑施工单位 要想有效提高土木工程的抗震性, 就需要对工程建筑的抗震 等级进行合理判定, 然后再展开抗震工程设计工作, 从而有 效提高土木工程施工质量。

\section{4 结束语}

总而言之, 随着城市发展步伐的加快, 人们生活水平直 线提升, 对土木工程的稳定性、美观性、坚固性等内容都有 了新的要求, 此种情况下, 建筑施工单位要想获取到最大化 经济效益, 就需要积极展开土木工程结构设计与地基加固工 作, 不断优化土木工程结构和地基加固技术, 将土木工程建 设中存在的缺点都及时解决, 从而有效保证土木工程施工质 量, 潜移默化中推动土木建筑行业的可持续发展。

\section{[参考文献]}

[1]吴晛.关于土木工程结构设计与地基加固技术认识 [J]. 商品与质量,2018,(17):111.

[2]魏文庆.关于土木工程结构设计与地基加固技术认识 [J]. 商品与质量,2018,(16):245-257.

[3]吴寒,张楚.关于土木工程结构设计与地基加固技术 认识[J].建材与装饰,2018,(18):129.

[4]张明,张勇.关于土木工程结构设计与地基加固技术 认识[J].消费导刊,2018,(25):86

[5]张怀升. 关于土木工程结构设计与地基加固技术认识 [J].建材与装饰,2018,(3):73.

[6]刘文浩.关于土木工程结构设计与地基加固技术认识 [J]. 商品与质量,2018,(6):72.

[7]周围.关于土木工程结构设计与地基加固技术认识 [J].建材发展导向(下),2018,16(7):306. 